\title{
FALSE HERMAPHRODITE IN P. B. SHELLEY'S ALASTOR, OR THE SPIRIT OF SOLITUDE
}

\author{
Roohollah Datli Beigi, University of Isfahan, Isfahan, Iran, \\ r.datli@fgn.ui.ac.ir
}

Pyeaam Abbasi, University of Isfahan, Isfahan, Iran, abbasi@fgn.ui.ac.ir

Zahra Jannessari Ladani, University of Isfahan, Isfahan, Iran

Original scientific paper

DOI: 10.31902/fll.36.2021.2

\begin{abstract}
Defined as the union of the most striking opposites and associated with Platonic perfection, the term hermaphrodite has a fondness for elevated places. The constellation of the hermaphrodite through the union of the male subject and the female object is a recurrent motif in Percy Bysshe Shelley's poems. Such a hermaphrodite in Shelley's repository usually leads to a sort of Platonic perfection in a paradisiacal realm or Elysium. The hermaphrodite in Shelley's Alastor, or The Spirit of Solitude, though constellated, does not lead to such a Platonic perfection but a purgatorial state for the visionary Poet as the Shelleyan hero. Focusing on the first part of the poem and using the concept of the hermaphrodite, this article strives to bring under scrutiny the destruction of Shelley's hero and his fall into the depth of a purgatorial state when the hermaphrodite is broken apart leading to the release of its either aggressive male or poisonous female energies which results in the transformation of the hero to a worm-like phallus at the end of the poem.
\end{abstract}

Keywords: Alastor, Elysium, Hermaphrodite, Female object, Male subject

\section{Introduction}

Referring to the process of composing a poem, Percy Bysshe Shelley writes in his A Defence of Poetry (1821) that "the mind in creation is as a fading coal" which has the potentiality of being awakened to "transitory brightness" through "some invisible influence" such as "an inconstant wind" (656). This invisible influence which "arises from within" (ibid) is in fact the poet's feminine soul as the origin or source of poetry whose union with the poet engenders the paradise of poetry. Asia in Shelley's Prometheus Unbound (1819) is such an anima-like feminine power whose union with Prometheus constellates the hermaphrodite the final result of which is an Elysium "All overgrown 
with trailing odorous plants, / Which curtain out the day with leaves and flowers" (III. iii. 11-12). The union of the poet and Emilia in Epipsychidion (1821) similarly leads to the constellation of a hermaphroditic wholeness and perfection in an "Elysian isle" where they are united to an original oneness which never parts again: "Two overshadowing minds, one life, one death, / One Heaven, one Hell, one immortality, / And one annihilation" (539; 585-7). The inseparable state of the lovers in this Elysium will provide them with "an awareness of that abiding One which overcomes mortal distinctions and individual differences" (Gurney 303). Although Shelley's Alastor, or The Spirit of Solitude (1815) also enjoys such a feminine power whose union with the visionary male Poet (as the poem's hero) constellates the hermaphrodite, the union is not an everlasting inseparable one leading to an enchanted paradise, but an impermanent separable one resulting in a purgatory. Reading Shelley's poem one may pose the question why the hermaphrodite in Alastor does not lead to a paradise like that of Shelley's The Revolt of Islam (1817) and Epipsychidion. False or negative hermaphrodite can provide the best answer to this question. Put concisely, the hermaphrodite in this poem is a false or negative one whose discrimination breaks apart the hermaphroditic wholeness to release its either aggressive masculine will or poisonous feminine will which are destructive. This article is thus an attempt to investigate the transition of Shelley's hero to a perfect wholeness and his consequent purgatorial state in the light of the hermaphrodite concept. In order to discuss the constellation and bifurcation of the hermaphroditic form in Shelley's Alastor and the purgatorial condition into which the hero descends, the very concept of the hermaphrodite needs to be elaborated upon succinctly.

\section{The Hermaphrodite}

Defined by Carl Gustav Jung as the "union of the strongest and most striking opposites" (CW9i 173) and associated with Platonic perfection, the term hermaphrodite has "a fondness for elevated places" (Jung, Aion 206). Frederic Colwell maintains that "the hermaphrodite knows nothing of the imperfections of the divided sexes and their lack of completeness" (175). The origin of the term can be traced back to "the sexual duality of early fertility deities of Asia Minor" and later to the mythological figure Hermaphroditus who as the bisexual child of Hermes and Aphrodite, and the symbol of androgyny and effeminacy was often portrayed as a female figure with male genitals (Paglia 125). As Jung relates, the religions of "Dionysus" and "Orpheus" bring forth "symbols associated with a god-man of androgynous character" (Man 
and His Symbol 141). For Jung, not only does the term refer to the bisexual nature of gods such as Osiris, Dionysus and Zeus, it also stands for a primitive state of mind which has been eliminated with the development of civilization. Talking about the concept, he claims that In the first place this union refers back to a primitive state of mind, a twilight where differences and contrasts were either barely separated or completely merged. With increasing clarity of consciousness, however, the opposites draw more and more distinctly and irreconcilably apart. If, therefore, the hermaphrodite were only a product of primitive non-differentiation, we would have to expect that it would soon be eliminated with increasing civilization. (CW9i 173-4)

Furthermore, Dionysus, with his half-male half-female appearance, "retains nothing male except a beard" (Paglia 89), making Roberto C Ferrari hail him as "a patron god of hermaphrodites and transvestites" (para. 3).

In Hermetic philosophy, the hermaphrodite is an Adamic one who despite having a masculine appearance "always carries about with him Eve, or his wife, hidden in his body" (Jung, CW11 para. 47). The alchemical-related "hermaphroditic rebis" (Jung, CW9i 174) played a crucial role in the natural philosophy of the Middle Ages where the term was defined as the reconciliation of spirit and matter, a being of both male and female qualities as indicated by the male and female head within a single body. Jung brings this duality to his psychology and argues that "anima" as "the female element in the male unconscious" gives rise to an "inner duality" that "is often symbolized by a hermaphroditic figure" (Man and His Symbols 30). This duality or the reconciliation of male and female aspects, however, was disintegrated "in the seventeenth century with the growth of a more rationalistic outlook" (Von Franz 235). Referring to the bifurcation of the hermaphrodite by philosophy, Ross Woodman relates that "translated into a philosophical concept it simply as androgyne ceases to be" (226). Given the fact that rationalism is a masculine Apollonian principle, it can be implied that the male-female equality of the hermaphrodite has been imbalanced by the growth of rationalistic philosophy in the seventeenth and eighteenth centuries. As a final point, it should be noted that the two terms of "androgyne" and "hermaphrodite" can be used interchangeably. While Paglia maintains that "the words hermaphrodite and androgyne should be virtually synonymous" (292), Samuel Foster Damon makes a distinction between these two concepts and argues that while the sexes are equal in androgyne "in which man's bisexual nature 
is perfectly harmonized," the female dominates in hermaphrodite (182). Using the words "perfectly harmonized," Damon implies that, regardless of being called androgyne or hermaphrodite, the dominance of either male or female sexes will erase perfection from the being. Examining Shelley's Alastor, or The Spirit of Solitude at length, this article explores the concept of negative or false hermaphrodite in this poem and shows how the bifurcation of the hermaphrodite leads to the purgatorial or liminal state of the poem's hero and, finally, his transformation into the worm-like phallus at the end of the poem.

\section{Discussion}

"Let us believe in a kind of optimism," wrote Shelley in one of his letters, "in which we are our own gods" (Essays II. 188). Referring to this letter of Shelley, Ross Woodman puts it that "Shelley's vision of sexual love is man and woman uniting to become their own god" (228). The visionary character of Shelley's Alastor rejects "the established social order" (Scrivener 84) and undergoes a backward and eastward journey leading to the union of the male subject and the female object at the end of the poem's first part. Undergoing a shift from society to nature, the visionary Poet tries to "leave the influence of society" and build a "direct contact with nature" (Richardson 176). Considering the Poet's contact with nature and his union with a female object, Michael Scrivener relates that "the union of subject and object, and the reconciliation of nature and man [...] are both Utopian images that promise a happy resolution sometime far in the future" (86). The union of the Poet and his anima (the veiled maiden) in the Poet's vision with its "irresistible joy" (186) in Alastor is such a union of the striking opposites of male and female or the male subject and his anima which results in a hermaphrodite. In this regard, James Hillman defines anima as "the carrier and even the image of 'wholeness'" that "completes the hermaphrodite both psychologically and as representative of man's biological contrasexuality" (99). However, as the sign of perfection, the hermaphrodite in Shelley's poem is bifurcated immediately after being constellated leaving the Poet in a purgatorial state. Functioning as the Poet's anima, the veiled maiden, thus, destroys him though she contributes primarily to the constellation of the hermaphrodite. Having in mind the seductive and destructive power of anima, Jung writes that "the insinuations of the anima, the mouthpiece of the unconscious, can utterly destroy a man" by making him "neglect reality" (Memories 187). As such, when his vision is swallowed up and he is awakened from his trance, the Poet finds himself surrounded by "The cold white light of morning, the blue moon / Low in the west, the clear and garish hills / 
The distinct valley and the vacant woods" (193-5). The perfection or paradise created by the constellation of the hermaphrodite thus disappears making the narrator to ask "Whither have fled / The hues of heaven that canopied his bower / Of yesternight?" (196-8). Although called by Richard Holmes an "unrealized sexual desire" (248), the result of this union in the form of sexual love is the creation of androgyne or hermaphrodite as a bisexual god, as elaborating upon the concept of hermaphrodite, Jung maintains that "the majority of cosmogonic gods are of a bisexual nature" (CW9i 173), that is, hermaphrodite. Such a sexual love, adds Woodman, "is the idealized sexuality of the hieros gamos imaged in Revelation as the New Jerusalem descending from Heaven as a bride to meet the bridegroom" (228). In other words, such an idealized sexual love or union is supposed to lead to the creation of the New Jerusalem as a perfect paradise through the constellation of the hermaphrodite. This union of man and woman in the form of sexual love to make them their own god - given that creation is the most prominent feature of gods - is the union of the poet and his own feminine soul "in a divine and unapprehended manner, beyond and above consciousness" which results in a Garden of Eden or rather paradise of poetry created "out of the wrecks of Eden" (Defence 640-41; 650). Put in other terms, the final outcome of this union is an imaginatively but fleetingly created paradise in Alastor by the union of the Poet and his feminine soul when the Poet becomes androgyne.

Nonetheless, in order for the hermaphroditic form to achieve perfection, the two genders should be equally involved or, in Paglia's words, gender has to be "eradicated and biology defied" (374). Accordingly, when one of the genders is dominant and assumes control, the hermaphrodite becomes a false or negative one that being broken apart releases its either poisonously feminine power or "the aggression of masculine will" (Paglia 291) both of which are poisonous and/or ruinous. This is especially the case in Alastor where the eradication of the male gender leads to the dominance of feminine will as the male subject is dissolved or assimilated into his anima and is thus controlled or subordinated by her. In his Myth, Truth and Literature (1989), Colin Falck introduces two faces of Romanticism, namely, "heroism" and "submissiveness" (2). Heroism, according to Falck, is associated with revolution that is reminiscent of "a Promethean conspiracy to steal fire from the gods" and encourages us "towards mastery" (1-2). Given the fact that "the fire was consciousness" (Falck 1), heroism brings the Romantic hero to a state of consciousness represented, for example, by the purgatorial state of Prometheus being chained to the rocks of Caucasus at the onset of Shelley's Prometheus Unbound. By contrast, 
submissiveness encourages us "towards submission" (Falck 2) or passiveness called by Coleridge "the dignity of passiveness to worthy Activity" (307). John Keats' "negative capability" defined as "when a man is capable of being in uncertainties, mysteries, doubts, without any irritable reaching after fact and reason" (60) corresponds to this submissiveness. The subordination or subjugation of Shelley's male heroes to their female souls or animas is such a submissiveness through which the male hero falls into the depth of unconscious. Withdrawing the male subject's masculine subjectivity, it transforms the male subject to a passive object capable of uncertainty, mystery and doubt. As the projections of Shelley's mind that, according to Paglia, "enjoyed subordination to female power" (372), Shelley's male heroes such as Prometheus, the Poet in Alastor and the hero of Epipsychidion intend to be subjugated or controlled by a female power. This subjugation, though not everlastingly, results in a paradise or a state of perfect union of male and female like the union of the Poet and the veiled maiden in Alastor as a result of reverie. Showing this tendency, Shelley writes in a letter to Mary that "Your thoughts alone can waken mine to energy [...] My understanding becomes undisciplined without you" (qtd. in Paglia 372).

In both Epipsychidion and Alastor, the male subject becomes a completely passive one being controlled by the female power. In Epipsychidion, the perfect hermaphrodite is achieved by a passive poet's glorification of Emilia as "an incestuous twin" and "a genderless spirit" and the formed hermaphrodite is a hermaphroditic rebis of alchemy that is often shown "as incestuous brother and sister" (Paglia 373; 210). Becoming one with his "vestal sister" (390) functioning as his anima or feminine soul, the Shelleyan hero descends to an idyllic Greek island where he and his anima become "The living soul of this Elysian isle, / Conscious, inseparable, one" (539-40). The remarkable feature of this union that distinguishes it from that of Alastor is that this hermaphroditic union of the poet and Emilia is perfectly inseparable as gender eradicates and the resulting hermaphrodite is a genderless one. The very fact that Shelley's hermaphrodite does not lead to a permanently perfect state in Alastor enhances the idea of the female's poisonous dominance in the unions of the genders. The delusive union of the Poet and the veiled maiden lasts only for few lines and the Poet awakens disappointedly to a cold place where "The cold white light of morning" is spread, the blue moon is "Low in the west" and the woods are vacant (193-6). Thus, when the Poet is awakened from his reverie to this reason-dominated situation, the hermaphrodite has been painfully bifurcated into male and female genders. Rationality or reason presented by the moon image is the agent of this bifurcation because 
the faculty of reason in Shelley's repository is offered, as Carlos Baker notes, through the "moon-symbol" (234). Reason is the faculty, writes Baker referring to Shelley's Epipsychidion, that rescues the soul from "false imagination" (235). Under the influence of reason, represented in Shelley by the moon-symbol or its cold light, "the soul in a creative sense is neither alive nor dead, but occupies some middle purgatory" (Baker 235). Accordingly, reason, as the faculty that rescues the soul from false imagination, rescues the soul of the Poet from the false hermaphrodite through breaking apart the false hermaphrodite form to release its male and female energies. It is false hermaphrodite as, first, its female energy is dominant and, second, as it is constellated in the Poet's reverie. In other words, after a short moment of perfect wholeness through the eradication of the sexes, the hermaphrodite is broken apart leading to the release of the poisonous feminine will the final result of which is destruction. This released feminine power can be witnessed in the ardent or rather tantalizing desire of the Poet that tickles and excites his soul for having a boat journey conducting him to his final phallic annihilation with the boat representing the Poet's ardent and at the same time perishing desire. "Then the boat," writes Hughes, "is desire or hope represented as in a state of pining, scarce seaworthy, driven by an improvised sail" (469). After the release of poisonous feminine power and being transformed into a worm-like phallus or "creeping worms" (622), the Poet becomes a dying and resurgent god like Dionysus or Osiris whose annihilation and resurrection is associated with "the permanence and continuity of life" (Jung, CW9i 117) which can be the subject of another study. However, it should be noted that the poem ends with annihilation, and the mentioned resurrection and continuity of life are postponed to an unborn future when a divine life is promised.

\section{Conclusion}

The creation of the hermaphrodite through the perfect union of the male subject and the female object resulting in a Platonic perfection or paradise is a recurrent theme in many of Shelley's poems. As a symbol of perfection, the hermaphrodite knows nothing of the imperfections of the divided sexes and their lack of completeness. Although constellated at the end of the first part of Alastor through the union of the visionary Poet and the veiled maiden, the hermaphrodite is not a positive one conducting the lovers to an either earthly or heavenly transcendental region but to a cold place leaving him in a purgatorial, uncertain or liminal state. Nor is it perfect as the sexes are divided in it, releasing its poisonous feminine will. The Platonic perfection is achieved only when the male subject is subjugated by the female power and the genderless 
or bisexual hermaphrodite is formed which has a fondness for elevated places. Such a paradise or elevated place is also created in Alastor when the visionary Poet is withdrawn from his constrained male subjectivity and bestows the control to the veiled maiden in an act of sexual dissolution. This paradise is not, however, an everlasting one and disappears immediately leaving the Poet in a cold place. This article was an attempt to show that the lack of a perfect paradise in this poem is due to the fact that the hermaphrodite constellated through the union of the male subject and the female object is a false one. Such a hermaphrodite, although eradicates gender and defies biology, has nothing to do with perfection as it is ephemeral and without any procreation or regeneration as the features of the perfect hermaphrodite. Imperfection of the hermaphrodite in this poem makes the Poet reach perfection in death at the end of the poem which probably will conduct him to a posthumous paradise in an unknown future. The hermaphrodite Shelley puts on display in this poem is no longer representative of Platonic perfection but, on the contrary, it offers an urgent warning against the inevitable poisonous and destructive consequences of such false hermaphrodite whose imbalanced sexes may lead to its hazardous bifurcation.

\section{Works cited:}

Baker, Carlos. Shelley's Major Poetry: The Fabric of a Vision. Princeton: Princeton UP, 1948.

Coleridge, Samuel Taylor. Coleridge's Notebooks: A Selection, edited by Seamus Perry, Oxford, Oxford University Press, 2002.

Colwell, Frederic S. Rivermen: A Romantic Iconography of the River and the Source. Oxford: McGill-Queen's University Press, 1989.

Damon, Samuel Foster. A Blake Dictionary: The Ideas and Symbols of William Blake, New Hampshire: University Press of New England, 2013.

Falck, Colin. Myth, Truth and Literature: Towards a True Post-modernism, Cambridge: Cambridge University Press, 1989.

Ferrari, Roberto C. "Subjects in the Visual Arts: Dionysus". glbtq.com. Archived from the original on July 12, 2009. Retrieved April 8, 2015.

Gurney, Stephen. "Byron and Shelley." English Romantic Poetry, edited by Harold Bloom. New York: Infobase Publishing, 2004, 289-317.

Hillman, James. "Anima." Spring, 1973.

Hughes, A. M. D. "Alastor, or the Spirit of Solitude." The Modern Language Review, vol. 43, no. 4, 1948, pp. 465-470.

Jung, C. G. Man and His Symbols, New York: Dell Pub. Co. 1964.

-----. The Archetypes and the Collective Unconscious, vol. 9i, translated by R. F. C. Hull, $2^{\text {nd }}$ edition, 1968.

-----. Aion: Researches into the Phenomenology of the Self, translated by R. F. G. Hull, New York: Pantheon Books, 1959. 
-----. Psychology and Religion: West and East, vol. 11, translated by R. F. C. Hull, $2^{\text {nd }}$ edition, Princeton: Princeton University Press, 1969.

------. Memories, Dreams, Reflections, edited by Richard and Clara Winston. New York: Vintage Books, 1989.

Keats, John. Selected Letters of John Keats, edited by Grant F. Scott, Massachusetts: Harvard University Press, 2002.

Paglia, Camille. Sexual Personae: Art and Decadence from Nefertiti to Emily Dickinson, New Haven: Yale University Press, 2001.

Richardson, Donna. "An Anatomy of Solitude: Shelley's Response to Radical Skepticism in 'Alastor'", Studies in Romanticism, vol. 31, no. 2, 1992, pp. 171-195.

Holmes, Richard. Shelley the Pursuit. New York: New York Review Books, 1994. Scrivener, Michael Henry. Radical Shelley: The Philosophical Anarchism and Utopian Thought of Percy Bysshe Shelley, Princeton: Princeton University Press, 1982.

Shelley, P. B. Essays, Letters from Abroad, Translations and Fragments. Vol II. London: Edward Moxon, 1852.

Von Franz, Marie-Louise. C.G. Jung: His Myth in Our Time, translated by William H. Kennedy. London: Hodder and Stoughton, 1975.

Woodman, Ross. "The Androgyne in 'Prometheus Unbound'", Studies in Romanticism, vol. 20, no. 2, 1981, pp. 225-247.

\section{FAUX HERMAPHRODITE DANS ALASTOR DE P. B. SHELLEY, OU L'ESPRIT DE LA SOLITUDE}

Défini comme l'union des contraires les plus frappants et associé à la perfection platonicienne, le terme hermaphrodite a un penchant pour les lieux élevés. La constellation de l'hermaphrodite par l'union du sujet masculin et de l'objet féminin est un motif récurrent dans les poèmes de Percy Bysshe Shelley. Un tel hermaphrodite dans le dépôt de Shelley conduit généralement à une sorte de perfection platonicienne dans un royaume paradisiaque ou Elysium. L'hermaphrodite dans Alastor de Shelley, ou L'esprit de la solitude, bien que constellé, ne conduit pas à une telle perfection platonicienne mais à un état purgatoire pour le poète visionnaire comme le héros Shelley. En se concentrant sur la première partie du poème et en utilisant le concept de l'hermaphrodite, cet article s'efforce de mettre en lumière la destruction du héros de Shelley et sa chute dans les profondeurs d'un état purgatoire lorsque l'hermaphrodite est brisé conduisant à la libération de son soit des énergies masculines agressives, soit des énergies féminines vénéneuses qui entraînent la transformation du héros en un phallus semblable à un ver à la fin du poème.

Mots-clés: Alastor, Elysium, Hermaphrodite, Objet féminin, Sujet masculin 